\title{
FORMALISASI PEMAKAIAN JILBAB DI INSTITUT AGAMA ISLAM MUHAMMADIYAH SINJAI
}

\author{
Oleh: Kusnadi ${ }^{1}$ \\ ${ }^{1}$ Institut Agama Islam Muhammadiyah Sinjai, \\ Jl. Sultan Hasanuddin, No. 20 Balangnipa, Sinjai \\ E-mail: adhybugiezgmail.com, Tlp: +628114178104
}

\begin{abstract}
Abstrak
Kajian tentang formalisasi pemakaian jilbab (suatu analisis paedagogis) yang bertujuan untuk menelaah dan mengetahui konsep kewajiban menutup aurat dan persepsi mahasiswi IAIM Sinjai tentang kewajiban memakai jilbab melalui tekhnik interviw, observasi dan angket. Data yang diperoleh dianalisis dengan menggunakan metode induktif, deduktif dan komparatif. Kewajiban memakai jilbab dikalangan mahasiswi di saat mengikuti perkuli memberikan dua sudut pandang yang berbeda dikalangan mahasiswi IAI Muhammadiyah Sinjai. Kelompok pertama adalah mahasiswi yang menyadari bahwa penggunaan jilbab merupakan kewajiban yang telah ditetapkan oleh syariat. Kedua adalah mahasisiwi menganggap sebagai kewajiban yang diterapkan dalam kampus sebagai kampus yang islmi, sehingga setiap mahasiswi wajib menggunakan jilbab ketika berada dalam kampus. Persepsi kedua diatas dapat dideskripsikan bahwa terdapat beberapa di antara mahasiswi yang tidak memakai jilbab ketika sudah berada di luar kampus yang tentunya sangat kontraks dengan pemahaman kelompok mahasiswi yang pertama.
\end{abstract}

\section{Kata Kunci: Jilbab dan Mahasiswi}

\section{PENDAHULUAN}

$\mathrm{P}$ ada beberapa dasawarsa yang lalu, pemakaian jilbab bagi para muslimah di Indonesia, mendapat tantangan yang cukup hebat. Mereka dianggap sebagai wanita yang kolot, terbelakang, atau tidak modern (Nashruddin Baidan, 1999: 117). Bahkan, bagi para karyawati muslimah yang bekerja di berbagai instansi pemerintah maupun swasta, selalu mendapat tekanan jika mengenakan jilbab, sebab dinilai melanggar disiplin berbusana yang telah ditetapkan instansi tersebut. Demikian halnya bagi para murid atau siswi yang belajar di sekolahsekolah umum, baik sekolah milik pemerintah maupun swasta, mereka tidak dibenarkan memakai jilbab, sebab dianggap melanggar ketentuan pakaian seragam yang telah ditetapkan sekolah yang bersangkutan.

Namun, pada dasawarsa terakhir ini, tantangan tersebut hampir tidak ditemukan lagi. Para muslimah sekarang merasa lebih berwibawa dan terhormat jika memakai jilbab (Nashruddin Baidan, 1999: 117-118). Para karyawati, murid, atau siswi sudah mendapat kebebasan mengenakan jilbab, sepanjang tidak mengganggu aktivitas kerja atau aktivitas belajar bagi mereka.

Khusus di tingkat Perguruan Tinggi, tidak ada hambatan bagi para mahasiswi muslimah dalam pemakaian jilbab, sebab aturan pakaian seragam di Perguruan Tinggi khususnya perguruan tinggi Islam mewajibkan mahasiswa untuk menggunakan busana islami. Para mahasiswa diberi kebebasan memilih bentuk pakaian, asal saja pakaian tersebut tergolong sopan dan tidak melanggar etika 
perkuliahan. Berbusana islami di sini ditafsirkan sebagai kewajiban memakai jilbab bagi para mahasiswi.

Jika diamati lebih lanjut, sebagian di antara mahasiswi IAIM Sinjai telah membawa tradisi kampusnya ke aktivitas luar kampus, meski demikian tidak menutup kemungkinan akan masih adanya beberapa mahasiswa yang belum sadar sepenuhnya dengan tanggung jawab tersebut. Dengan kata lain, sebagian di antara mereka tidak melepaskan jilbabnya meski berada di luar kampus, namun sebagian pula yang tidak lagi mengenakan jilbab jika sudah berada di luar kampus.

Berangkat dari fenomena ini, maka penulis tertarik untuk mengkaji lebih lanjut persepsi mahasiswi terhadap formalisasi pemakaian jilbab (suatu analisis pedagogis) dengan sub tema penelitian yang membahas tentang kewajiban menutup aurat dalam konsep ajaran Islam, aplikasi peraturan berjilbab dalam mengikuti perkuliahan, dan persepsi mahasiswi tentang kewajiban memakai jilbab.

Penelitian ini menggunakan pendekatan yuridis dan sosiologis. Pendekatan pertama, yakni meninjau persoalan jilbab dan kewajiban menutup aurat dari sudut ilmu fikih. Sementara pendekatan kedua, mengamati kondisi nyata terhadap sebagian mahasiswi IAIM Sinjai yang hanya memakai jilbab ketika berada di lingkungan kampus, tetapi ketika berada di luar kampus, maka ia pun melepas jilbabnya.

\section{PEMBAHASAN}

\section{A. Pengertian dan Dasar Hukum Kewajiban Menutup Aurat}

1. Pengertian Aurat

Kata عورات عerasal dari akar kata عار yang berarti "membawa, merusak, membelokkan, memalingkan, dan menyimpang". Dari akar kata ini terbentuk kata العورة yang berarti "aurat", sehingga klausa بدت عورنت berarti “tampak auratnya" (Ahmad Warson Munawwir, t.th.: 1057).

Ada pula yang mengartikan aurat sebagai barang yang buruk. Dari kata itu, ada sebutan 'aurat (عَوْرَاءُ) yang berarti wanita buruk karena matanya hanya satu (Abu Rifqi al-Hanif dan Lubis Salam, 1994: 14). Sedangkan yang dimaksud di sini adalah bagian tubuh yang tidak patut diperlihatkan kepada orang lain. Dan bagian-bagian itu ada bermacam-macam sesuai dengan tempat dan situasinya.

Adapun yang perlu diperhatikan disini terkait dengan masalah aurat adalah bahwa wanita itu wajib hukumnya menjaga dirinya, agar jangan sampai memperlihatkan auratnya kepada orang lain yang tidak diizinkan untuk melihatnya, sehingga mendapatkan ridha Allah dan berhak tinggal di dalam surga yang telah dipersiapkan Allah bagi mereka yang bertakwa.

2. Dasar Hukum Kewajiban Menutup Aurat

Pada dasarnya, dasar hukum kewajiban menutup aurat dalam syari'at Islam ada dua, yaitu alQur'an dan al-Hadis. Dalam QS al-Nür/24: 31, Allah berfirman: 


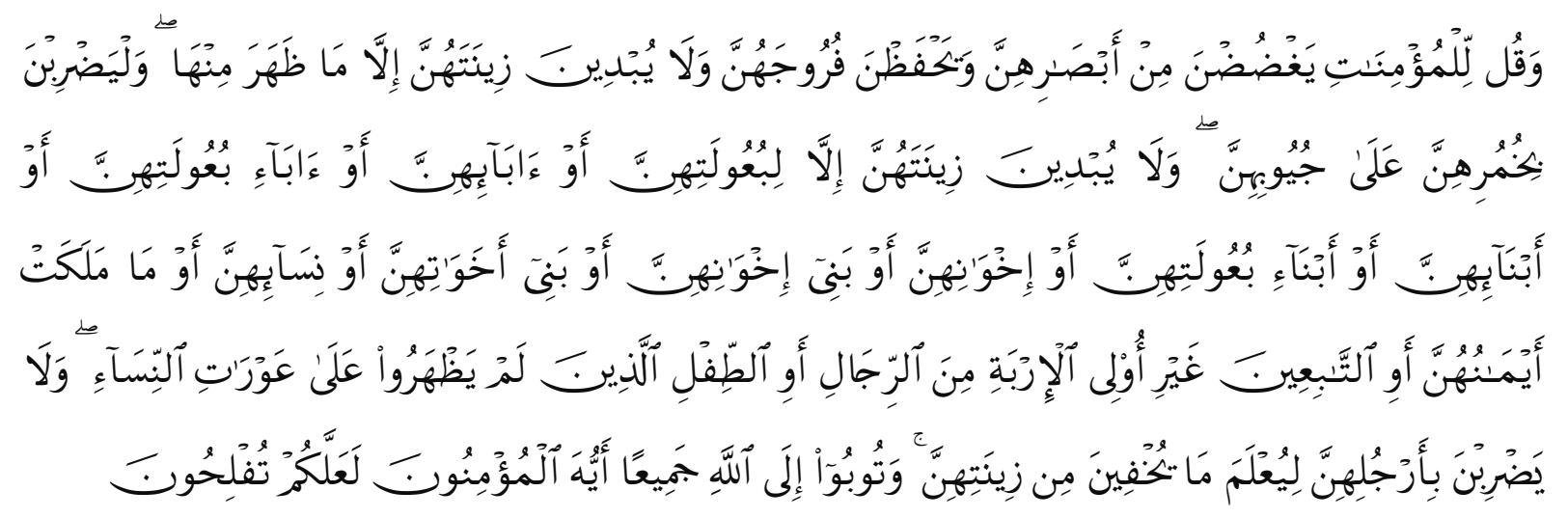

Terjemahnya:

"Katakanlah kepada wanita yang beriman: "Hendaklah mereka menahan pandangannya, dan memelihara kemaluannya, dan janganlah mereka menampakkan perhiasannya, kecuali yang (biasa) nampak daripadanya. Dan hendaklah mereka menutupkan kain kudung ke dadanya, dan janganlah menampakkan perhiasannya, kecuali kepada suami mereka, atau ayah mereka, atau ayah suami mereka, atau putera-putera mereka, atau putera-putera suami mereka, atau saudarasaudara laki-laki mereka, atau putera-putera saudara laki-laki mereka, atau putera-putera saudara perempuan mereka, atau wanita-wanita Islam, atau budak-budak yang mereka miliki, atau pelayan-pelayan laki-laki yang tidak mempunyai keinginan (terhadap wanita) atau anakanak yang belum mengerti tentang aurat wanita. Dan janganlah mereka memukulkan kakinya agar diketahui perhiasan yang mereka sembunyikan. Dan bertaubatlah kamu sekalian kepada Allah, hai orang-orang yang beriman supaya kamu beruntung" (Departemen Agama, 1985/1986: 548).

Dalam QS al-Nür/24: 31 yang tersebut di atas secara tegas memerintahkan kaum wanita mukmin agar menjaga kehormatan dan menutup auratnya dari orang-orang yang tidak boleh melihatnya. Hal ini terkait dengan pendapat Maulana Muhammad Ali bahwa ayat ini turun untuk menegur wanita-wanita Arab yang pada waktu itu gemar mempertontonkan kemolekan tubuh mereka di hadapan umum, seperti membuka dadanya. Karenanya, mereka diperintahkan berpakaian sopan jika sedang berada di tengah-tengah masyarakat umum (Maulana Muhammad Ali, 1977: 441).

Di samping al-Qur'an, juga terdapat Hadis Nabi yang memberikan tuntunan secara moral mengenai larangan menampakkan aurat Sebagaimana yang diriwayatkan oleh Abu Daud sebagai berikut (Abu Daud, t.th.:60-61):

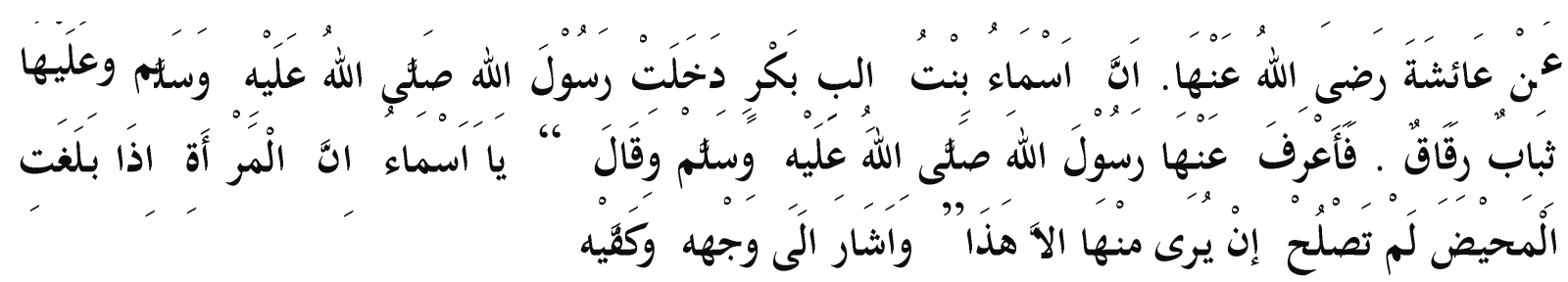

Artinya:

'Dari Aisyah r.a., sesungguhnya Asma' anak perempuannya Abu Bakar, bahwa sanya suatu hari Asma' pergi bertamu ke rumahnya Rasulullah Saw. Di saat Asma' bertamu ke rumahnya Nabi, Asma' mengenakan pakaian (baju) yang tipis. Ketika Nabi melihat Asma' dengan pakaian yang tipis langsung seketika itu Nabi berpaling dari arahnya Asma' lalu nabi bersabda kepada Asma': "Wahai Asma', sesungguhnya perempuan jikalau sudah baliq/haid maka tidak 
pantas jika di lihat auratnya oleh laki-laki yang bukan mahramnya, kecuali ini” Dan ini yang boleh di lihat kata nabi sambil isyarat menunjuk wajah dan telapak tangannya."

Berdasarkan hadis tersebut di atas maka dapat dipahami bahwa setelah perempuan mencapai umur baliq yang ditandai dengan datangnya haid, maka sejak itu pulalah seluruh tubuhnya menjadi haram untuk di lihat atau diperlihatkan kepada laki-laki yang bukan mahramnya kecuali wajah dan telapak tangannya.

Selanjutnya, pada QS al-Nür/24: 30 dan 31 para ulama sepakat mengenai kewajiban menutup aurat bagi seorang muslim. Hal itu secara eksplisit dapat dipahami dari perintah menahan pandangan dan memelihara kemaluan. Adapun secara implisit, QS al-Nūr/24: 31 melarang wanita memperlihatkan perhiasannya, kecuali kepada suaminya dan orang-orang yang terkait hubungan kemahram-an dengannya, serta terhadap laki-laki dan anak-anak yang belum mengerti tentang aurat wanita. Namun demikian, para ulama tidak sepakat mengenai batas aurat dari tubuh manusia yang harus selalu ditutup.

\section{B. Pendapat Beberapa Ulama tentang Kewajiban Menutup Aurat}

Pendapat para ulama tentang kewajiban menutup aurat berbeda-beda, hal ini disebabkan oleh sudut pandang yang berbeda dan kondisi ulama pada waktu itu. Namun pada dasarnya maksud dan tujuan mereka sama dan para ulama dalam mengambil suatu kesimpulan bersumber pada hal yang sama, yaitu kitabullah dan sunnaturrasul. Berikut pendapat beberapa ulama tentang kewajiban menutup aurat.

M. Quraish Shihab mendefinisikan aurat sebagai bagian anggota tubuh yang tidak boleh tampak, kecuali oleh orang-orang tertentu. Bahkan, bukan hanya kepada orang tertentu selain pemiliknya, Islam tidak senang bila aurat, khususnya "aurat besar" (kemaluan), dilihat oleh siapa pun; sebab ide dasar aurat adalah tertutup atau tidak dilihat, meski oleh yang bersangkutan sendiri (Quraish Shihab, 2003: 162-163).

Imam Malik, al-Syafi'iy, dan Abu Hanifah berpendapat bahwa laki-laki wajib menutup seluruh tubuhnya mulai dari pusar hingga lututnya. Meski demikian, ada juga ulama yang berpendapat bahwa yang wajib ditutup dari anggota tubuh laki-laki hanya yang terdapat di antara pusar dan lututnya, yaitu kemaluan dan pantatnya (Quraish Shihab, 2003: 162-163).

Adapun bagi wanita, menurut Abu Bakr ibn 'Abd al-Rahman, mereka wajib menutup seluruh anggota tubuhnya. Sebagian besar ulama, di antaranya al-Syafi'iy dan Malik berpendapat bahwa aurat wanita adalah seluruh tubuhnya, kecuali muka dan kedua telapak tangannya. Sedangkan Abu Hanifah sedikit lebih longgar, karena menambahkan bahwa selain muka dan kedua telapak tangan, kaki wanita juga boleh terbuka (Quraish Shihab, 2003: 162-163).

Al-Jazariy mempunyai pendapat tersendiri mengenai aurat wanita. Ia mengatakan bahwa ketika wanita sedang salat atau sedang berada di tengah laki-laki yang bukan mahram-nya, auratnya adalah seluruh organ tubuhnya, kecuali muka dan kedua telapak tangannya. Adapun ketika ia 
sendirian, atau berada di tengah wanita muslimah lainnya, atau sedang berada di tengah laki-laki mahram-nya, auratnya adalah bagian tubuh yang ada di antara pusar dan lututnya (Abd al-Rahman alJazariy, t.th.: 192).

Pendapat al-Jazariy mengenai batas aurat wanita di tengah laki-laki mahram-nya, termasuk pendapat yang terlonggar di antara beberapa pendapat ulama lain. Membolehkan wanita menampakkan buah dadanya terhadap laki-laki mahram-nya, merupakan pendapat yang kontroversial. Buah dada termasuk salah satu organ tubuh wanita yang sangat vital menimbulkan rangsangan bagi laki-laki. Lagi pula hubungan ke-mahram-an bukanlah suatu jaminan tidak timbulnya rangsangan dan gairah seksual di antara kedua belah pihak (Hasil Diskusi FPI, 188: 2). Kenyataan sosial membuktikan bahwa banyak di antara ayah yang dengan mata gelap memperkosa puteri kandungnya sendiri. Sebaliknya, tidak jarang terjadi seorang anak memperkosa ibu kandungnya sendiri.

Oleh karena itu, untuk menghindari terjadinya hubungan seksual di antara pihak-pihak yang terlarang untuk kawin, maka sebaiknya diikuti pendapat Imam Malik dan Ahmad bahwa bagian tubuh wanita yang boleh tampak bagi mahram-nya, hanya terbatas pada wajah, kepala, tengkuk, kedua tangan, kedua betis, dan kedua kakinya (Abd al-Rahman al-Jazariy, t.th.: 192). Dengan pembatasan seperti ini, timbulnya rangsangan yang dapat mengarah kepada kebiadaban, paling tidak, dapat diminimalisir.

Oleh karena itu, dalam $Q S$ al-Nür/24: 31 secara tegas memerintahkan kaum wanita mukmin agar menjaga kehormatan dan menutup auratnya dari orang-orang yang tidak boleh melihatnya. Untuk itu, ada dua hal yang perlu diperjelas mengenai kandungan ayat tersebut, yaitu:

1. Model Pakaian Wanita

Sejak dini, Allah Swt. telah mengilhami manusia sehingga timbul dalam dirinya dorongan untuk berpakaian. Dorongan tersebut diciptakan Allah dalam naluri manusia yang memiliki kesadaran kemanusiaan. Jika diperhatikan ayat-ayat al-Qur'an, sejak semula Adam dan Hawa tidak saling melihat aurat mereka, bahkan aurat masing-masing tertutup sehingga mereka sendiri pun tidak dapat melihatnya. Setelah itu, setan merayu keduanya agar memakan buah pohon terlarang, dan akibatnya, aurat yang tadinya tertutup menjadi terbuka. Setelah keduanya menyadari hal itu, mereka berusaha menutupinya dengan daun-daun surga ( $Q S$ al-A'raf/7: 20-22). Adam dan Hawa bukan sekadar mengambil satu lembar daun untuk menutup auratnya, melainkan sekian banyak lembar agar melebar, dengan cara menempelkan selembar daun di atas lembar lain, sebagai tanda bahwa pakaian tersebut sedemikian tebal sehingga tidak transparan atau tembus pandang (Quraish Shihab, 2003: 158-159).

Usaha yang dilakukan oleh Adam dan Hawa di atas menunjukkan adanya naluri pada diri manusia sejak awal kejadiannya bahwa aurat harus ditutup dengan cara berpakaian. Pakaian yang 
digunakan oleh mereka adalah pakaian yang tebal dan lebar sehingga betul-betul dapat menyembunyikan auratnya agar tidak terlihat oleh orang lain.

Setelah kehidupan manusia mengalami perkembangan, maka ikut pula berkembang model pakaian yang mereka gunakan sesuai dengan kondisi daerahnya. Setiap daerah mempunyai model pakaian tersendiri sebagai ciri khasnya, terutama bagi kaum wanitanya.

Pada zaman jahiliyah, para wanita Arab memakai kerudung dengan model terbentang ke belakang, sehingga leher dan bagian dada mereka terbuka lebar (Muhammad ibn 'Aliy ibn Muhammad al-Syaukani, t.th.: 22). Oleh karena itu, turunlah QS al-Nür/24: 31 dengan penekanan pada klausa وليضربن بخمرهن على جيوبهن sebagai perintah bagi mereka untuk membentangkan kerudung yang dipakainya ke depan sehingga kepala, tengkuk, dan dada mereka tidak terlihat oleh orang lain (Ahmad Mushthafa al-Maraghi, t.th.: 99). Model pakaian seperti inilah yang berkembang bagi kaum salaf yang hidup di Andalusia dan Mesir, digunakan oleh para wanita, laki-laki, maupun anak-anak (Abiy ‘Abdillah Muhammad ibn Ahmad al-Anbariy al-Qurthubi, 1994: 213).

Dewasa ini, pada umumnya kaum wanita senang menonjolkan dandanannya dengan model pakaian yang dinilainya sebagai modern. Di antara model yang digemarinya adalah pakaian tipis dan transparan, sehingga sekujur tubuhnya dapat kelihatan dengan jelas. Selain itu, ada juga wanita yang gemar memakai model pakaian yang hanya menutup buah dada ke bawah, sehingga kepala, leher, dan pangkal buah dadanya dapat dinikmati oleh orang yang ada di sekitarnya (Nadiyah Salim, 1994: 59). Model-model pakaian modern seperti ini jelas-jelas telah bergeser dari ide dasar pakaian sebagai penutup aurat.

Islam menganjurkan kepada para wanita muslimah agar dalam memilih model pakaian, tidak terpengaruh oleh model Barat yang dianggap trend dan modern, tetapi sesungguhnya telah keluar dari fungsi pakaian yang sesungguhnya. Al-Qur'an memberi kebebasan kepada umat Islam untuk memilih model pakaian yang disukainya, tetapi tidak terlepas dari empat fungsinya, yaitu:

a. Penutup aurat. Baik laki-laki maupun wanita, mereka harus memilih pakaian yang dapat menutup auratnya agar tidak terlihat oleh orang lain.

b. Perhiasan. Dalam fungsinya sebagai perhiasan, pakaian yang dipilih harus sesuai dan serasi dengan tubuh yang memakainya, sehingga tampak elok dan indah.

c. Perlindungan. Secara fisik, pakaian berfugsi melindungi pemakainya dari sengatan matahari dan sengatan dingin. Selain itu, secara psikologis, pakaian dapat mempengaruhi jiwa pemakainya menjadi percaya diri atau merasa rikuh dan risih.

d. Penunjuk identitas. Dengan pakaian yang dikenakannya, seseorang dapat diketahui identitasnya sebagai polisi, militer, atau pejabat Negara (Quraish Shihab, 2003: 161-171).

2. Perhiasan yang Boleh Dipakai Wanita

Perhiasan adalah sesuatu yang dipakai untuk memperelok dan memperindah pemakainya. Karenanya, pemakai perhiasan itu harus lebih dahulu menganggap bahwa perhiasan tersebut indah, 
meski orang lain tidak menilainya indah atau pada hakikatnya memang tidak indah. Keindahan adalah sesuatu yang menjadi dambaan setiap manusia, namun keindahan itu sangat relatif, tergantung dari sudut pandang masing-masing penilai.

Al-Qur'an tidak melarang manusia memakai perhiasan yang disukainya, karena yang demikian itu adalah naluri manusiawi. Yang dilarang adalah tabarruj al-jăhiliyyah, suatu istilah yang digunakan al-Quran (QS. al-Aḥzab/33: 33), yang mencakup segala macam cara yang dapat menimbulkan rangsangan bagi lawan jenis, seperti menggunakan wangi-wangian yang menusuk hidung (Quraish Shihab, 2003: 68).

Menurut M. Quraish Shihab, makna kata zina dalam QS al-Nür/24: 31 adalah perhiasan. Perhiasan adalah segala sesuatu yang digunakan untuk memperelok tubuh, baik pakaian, emas, maupun bahan-bahan make up (Quraish Shihab, 2003: 173). Al-Anbariy, sebagaimana dikutip oleh Abd al-Halim al-Syuqqah, mengatakan bahwa perhiasan itu ada dua macam: (1) perhiasan yang tersembunyi, seperti gelang kaki, gelang tangan, anting-anting, dan kalung; (2) perhiasan lahir (yang tampak), yaitu pakaian (Abd al-Halim Abi Syuqqah, 1991: 66).

Penggalan ayat yang berbunyi إلا ماظهر منها (kecuali apa yang biasa tampak) menjadi perbicangan kontroversi di kalangan ulama tafsir. Ibn Mas'ud mengatakan bahwa yang boleh tampak pada diri wanita adalah pakaiannya. Sa'ad ibn Jubair menambahkannya dengan pakaian dan wajah sekaligus. 'Atha' dan al-Auza'iy membolehkan tampak wajah dan kedua telapak tangannya. Ibn 'Abbas, Qatadah, dan Mizwar ibn Makhzamah berpendapat bahwa yang boleh tampak termasuk juga celak mata, gelang, setengah dari tangan (yang dalam kebiasaan wanita Arab diwarnai dengan pacar), anting, dan cincing (Muhammad ibn 'Aliy ibn Muhammad al-Syaukani, t.th.: 211).

Untuk meluruskan pemahaman terhadap redaksi penggalan ayat di atas, M. Quraish Shihab mengemukakan tiga pendapat: Pertama, memahami kata إلا dalam arti istisna munqati', sesuatu yang dikecualikan, bukan jenis yang disebutkan sebelumnya. Ini berarti: “Janganlah mereka menampakkan hiasan mereka sama sekali, tetapi apa yang tampak secara terpaksa, seperti ditiup angin, maka itulah yang dibolehkan”. Kedua, menyisipkan kalimat yang menjadikan penggalan ayat itu mengandung pesan lebih kurang: "Janganlah mereka menampakkan hiasan mereka. Mereka berdosa jika berbuat demikian. Namun, jika tampak tanpa disengaja, maka mereka tidak berdosa”. Ketiga, memahami klausa إلا ماظهر منها dalam arti yang biasa atau dibutuhkan keterbukaannya sehingga harus tampak. Kebutuhan di sini dalam arti menimbulkan kesulitan bila bagian tubuh tersebut ditutup (M. Quraish Shihab, 2003: 174-175).

Masalah lain yang perlu dijelaskan di sini adalah kebiasaan yang dimaksudkan ayat tersebut; apakah kebiasaan itu berkaitan dengan kebiasaan wanita pada masa turunnya ayat tersebut, atau kebiasaan wanita di setiap masyarakat Muslim dalam masa yang berbeda? Al-Qurtubiy misalnya memahami kebiasaan yang dimaksud sebagai kebiasaan wanita pada masa turunnya al-Qur'an. AlQurtubiy Berbeda dengan al-Qaffal bahwa kebiasaan tersebut adalah apa yang biasa tampak dari 
manusia sesuai dengan kondisi sosial setempat. Para wanita diperintahkan menutup sesuatu yang tidak perlu dibuka, kecuali karena darurat. Mereka diperkenankan membuka apa yang biasa terbuka dan perlu ditampakkan, sebab syariat Islam itu lurus, mudah, dan toleran (Al-Qurthubi, 1994: 212).

Abd al-Halim Abi Syuqqah merinci beberapa perhiasan wanita yang boleh ditampakkan, yaitu: (1) perhiasan wajah yang meliputi wangi-wangian dan celak mata, (2) perhiasan telapak tangan yang meliputi pewarna kuku, cincing, dan gelang, (3) perhiasan tumit berupa cincing pada jari kaki, (4) hiasan pakaian dalam bentuk keserasian dan keindahan warna (Abd al-Halim Abi Syuqqah, 1991: 342-352)

Di sini perlu dipertegas bahwa perhiasan wanita yang dapat ditoleransi adalah yang tidak menarik perhatian dan tidak membangkitkan syahwat laki-laki, baik dari niat si wanita maupun dari pengaruh yang disebabkan oleh warna dan model yang beraneka ragam.

Oleh karena itu, perhiasan itu sebaiknya digunakan untuk keperluan sebagai berikut: Pertama, jika ia masih gadis, maka ia berhias untuk para peminang. Kedua, jika ia janda, maka ia juga berhias untuk para peminang. Ketiga, jika ia bersuami, maka ia berhias untuk suaminya dengan hiasan lahir dan hiasan batin.

\section{Nilai-Nilai Edukatif dalam Pemakaian Jilbab}

Dalam salah satu riwayat disebutkan bahwa pada masa Rasulullah, para wanita mukminat pada malam hari sering keluar rumah untuk buang hajat. Di tengah perjalanan, mereka diganggu oleh orang-orang munafik, karena penjahat tersebut tidak bisa membedakan antara wanita merdeka (terhormat) dengan yang budak, sebab pakaian yang mereka gunakan sama. Ketika mereka melihat seorang wanita memakai tutup kepala (kerudung), mereka berkata: "Ini wanita merdeka", lalu mereka biarkan berlalu tanpa diganggu. Sebaliknya, jika mereka melihat wanita tanpa tutup kepala, mereka berkata: "Ini seorang budak perempuan", lalu mereka buntuti dengan tujuan untuk melakukan pelecehan seksual (Abu al-Hasan 'Aliy al-Wahidi, 1984: 382-383).

Oleh karena itu, tujuan dianjurkan untuk memakai jilbab bagi kaum muslimat tersebut adalah sebagai simbol keislaman, sekaligus sebagai pembeda antara wanita-wanita mukmin dengan wanitawanita lainnya, supaya mereka tidak lagi diganggu oleh pria-pria munafik sebagaimana yang dijelaskan dalam salah satu riwayat tersebut di atas.

Pada umumnya ulama tafsir mendefinisikan jilbab sebagai pakaian yang lebih besar daripada kerudung. Berkata al-Qana', jilbab adalah pakaian yang menutup seluruh tubuh wanita. Diriwayatkan dari Ibn 'Abbas dan Ibn Mas'ud bahwa jilbab adalah selendang (Abiy 'Abdillah Muhammad ibn Ahmad al-Anbariy al-Qurthubi, 1994: 220). Menurut M. Quraish Shihab, jilbab adalah baju kurung yang longgar, dilengkapi dengan kerudung sebagai penutup kepala (M. Quraish Shihab, 2003: 172). Dari berbagai pendapat tersebut, Nashruddin Baidan berkesimpulan bahwa meski banyak pendapat yang berkenan dengan pengertian jilbab, namun semua pendapat tersebut mengacu kepada satu bentuk pakaian yang menutup sekujur tubuh pemakainya (Nashruddin Baidhan, 1999: 118). 
Adapun cara mengulurkan jilbab, menurut Ibn 'Abbas dan 'Ubaidah al-Salmaniy, yaitu apabila wanita melipatkannya sehingga tidak tampak dirinya, kecuali hanya satu mata yang dengannya dia melihat. Dalam pendapatnya yang lain, Ibn 'Abbas dan Qatadah mengatakan bahwa wanita melipatkannya ke dahi dan mengikatkannya kemudian menjulurkannya ke hidung, meski kedua mata pemakainya terlihat, tetapi tetap menutup dada dan bagian mukanya selendang (Abiy 'Abdillah Muhammad ibn Ahmad al-Anbariy al-Qurthubi, 1994: 220).

Mengacu asbāb al-nuzūl QS al-Ahzab/33: 59, maka dapat dipahami bahwa secara jelas alQur'an menuntun kaum muslimah agar jilbab yang mereka pakai hendaknya diulurkan ke dada mereka, sehingga mereka dapat dibedakan dengan yang bukan muslimah yang memakai pakaian tidak terhormat sehingga mengundang gangguan tangan atau lidah yang usil. Ayat ini menunjukkan bahwa sejak semula para wanita muslimah telah memakai jilbab, tetapi cara pemakaiannya belum menghalangi gangguan dan belum menampakkan identitas muslimah (M. Quraish Shihab, 2003: 171172). Ini berarti bahwa jilbab disyariatkan untuk menyempurnakan keadaan wanita ketika mereka keluar rumah. Dalam kesempurnaan ini, terdapat kesempurnaan pembedaan, penjagaan diri, dan penghormatan ('Abd al-Halim Abi Syuqqah, 1991: 57).

Menurut Nashruddin Baidan, ayat ini turun bukan hanya berkenaan dengan konteks menutup aurat bagi wanita, tetapi lebih dari itu, yakni agar mereka tidak diganggu oleh pria-pria nakal. Dengan demikian, di wilayah mana pun di dunia ini, baik dahulu maupun sekarang, bila dijumpai kasus yang sama kriterianya dengan peristiwa yang melatarbelakangi turunnya ayat ini, maka hukumnya pun sama. Hal ini sesuai dengan kaidah uṣūl al-fiqh yang berbunyi: "Hukum syarak didasarkan pada 'illat-nya ada atau tidak ada 'illat tersebut. Jika 'illat ada, maka ada pula hukumnya. Sebaliknya, jika tidak ada 'illat, maka tidak ada hukumnya". Berdasar pada kaidah ini, maka kewajiban berjilbab menurut ayat ini bersifat kondisional, bukan kewajiban mutlak. Artinya, apabila di suatu masa atau pada suatu tempat, orang yang melihat wanita berpakaian mini dapat membangkitkan nafsu seks lawan jenisnya, sehingga mendorongnya untuk mengganggu wanita itu, maka dalam kondisi seperti itu wanita wajib memakai jilbab, supaya dia dapat berjalan bebas tanpa diganggu ('Abd al-Halim Abi Syuqqah, 1991: 57).

Ibn Rusyd, sebagaimana dikutip oleh 'Abd al-Halim Abi Syuqqah mengatakan bahwa, para ulama berbeda pendapat mengenai perintah dan larangan yang mengandung 'illat hukum yang maknanya dapat dipahami, apakah 'illat yang dipahami dari perintah dan larangan itu sebagai indikasi yang memungkinkan untuk mengubah dari wajib ke anjuran dan mengubah larangan dari haram ke makruh, ataukah 'illat itu bukan indikasi. Hukum-hukum yang dapat dipahami maknanya di dalam syarak kebanyakan termasuk bagian akhlak yang baik (maḥāsin al-akhlāq) atau termasuk bagian kemaslahatan. Yang demikian itu kebanyakan menunjukkan anjuran (mandūb) ('Abd al-Halim Abi Syuqqah, 1991: 65). Secara tersirat, pernyataan Ibn Rusyd ini mengandung makna bahwa perintah memakai jilbab bukan sebagai kewajiban, tetapi hanya berupa anjuran. 
Mengenai model jilbab seperti yang disebutkan dalam QS al-Ahzab/33: 59, Ibn 'Asyur mengatakan bahwa ayat ini mengandung ajaran yang mempertimbangkan adat orang-orang Arab, sehingga bangsa lain yang tidak menggunakan jilbab, tidak berlaku bagi mereka ketentuan ayat ini (Muhammad Tahir Ibn 'Asyur, t.th.: 19). Cara memakai jilbab dapat berbeda sesuai dengan perbedaan keadaan wanita dan adat mereka. Namun, tujuan perintah ayat ini adalah agar mereka dapat dikenal sebagai muslimah yang baik sehingga tidak diganggu (Muhammad Tahir ibn 'Asyur, t.th.: 102).

Terkait dengan model pakaian tersebut, maka dapat dikatakan bahwa, wanita yang menutup seluruh tubuhnya kecuali wajah dan telapak tangannya, telah menjalankan bunyi teks $Q S$ alAhzab/33: 59. Namun, pada saat yang sama, kita tidak wajar menyatakan terhadap mereka yang tidak memakai kerudung atau yang menampakkan tangannya sebagai orang yang secara pasti telah melanggar petunjuk ayat.

\section{Penelitian Pemakaian Jilbab}

1. Aplikasi dan Aturan Jilbab di IAI Muhammadiyah Sinjai

Berdasarkan hasil penelitian yang dilakukan, peneliti menemukan bahwa belum ada aturan tersendiri tentang mekanisme pemakaian jilbab di IAIM Sinjai, baik di STATUA maupun di lainlainnya, yang ada hanya penyampaian dosen tentang aturan perkuliahan yang terdapat pada kontrak kuliah yang dibuat oleh dosen itu sendiri, dimana didalamnya memuat tentang tatib perkuliahan dan etika perkuliahan yang disampaikan oleh dosen pengajar masing-masing.

Hasil pengamatan penulis menunjukkan bahwa TATIB di atas belum berjalan secara efektif. Buktinya, sampai sekarang ini, model jilbab yang dipakai oleh para mahasiswi masih bervariasi. Hasil pengamatan penulis ini diperkuat dengan hasil angket yang menunjukkan bahwa para mahasiswi sendiri mengakui kalau jilbab yang mereka pakai itu belum sepenuhnya mencerminkan busana Muslimah. Hasil angket tersebut akan dipaparkan dalam tabel berikut.

Tabel 1: Distribusi Tanggapan Para Mahasiswi Tentang Model Jilbab

\begin{tabular}{|c|l|c|}
\hline No & \multicolumn{1}{|c|}{ Tanggapan tentang Model Jilbab } & Prosentase \\
\hline 1 & Sudah sesuai dengan busana Muslimah & 12 \\
2 & Sebagian sesuai dan sebagian pula tidak sesuai dengan busana & 85 \\
& muslimah & 3 \\
\hline 3 & Belum sesuai dengan busana muslimah & 100 \\
\hline
\end{tabular}

Tabel di atas menunjukkan bahwa $12 \%$ dari para mahasiswi yang menilai bahwa pada umumnya model jilbab yang mereka pakai itu sudah mencerminkan busana Muslimah yang sesungguhnya, sedangkan $85 \%$ yang menilai bahwa hanya sebagian dari model jilbab yang mereka 
pakai sesuai dengan esensi busana Muslimah, sementara itu $3 \%$ sisanya yang menganggap kalau model jilbab yang mereka pakai itu belum ada yang sesuai dengan esensi busana Muslimah.

Untuk menyatukan model jilbab yang bervariasi dan beragam tersebut, diperlukan peraturan yang resmi dari pihak institusi, agar model jilbab yang dipakai para mahasiswi IAIM benar-benar mencerminkan busana Muslimah.

Satu-satunya aturan yang selama ini dipandang ampuh dalam menyatukan model jilbab para mahasiswi adalah kode etik yang dikeluarkan oleh Panitia Ujian Akhir Semester (UAS). Ketika akan dilaksanakan UAS, baik pada semester ganjil maupun pada semester genap, sudah dibakukan model pakaian yang harus dipakai oleh para peserta ujian melalui Kode Etik. Adapun bunyi Kode Etik Peserta Ujian yang terkait dengan busana adalah perintah memakai: (1) baju kemeja (bukan baju kaos), dan khusus bagi wanita tidak boleh ketat (warna putih); (2) celana (bagi pria) dan rok (bagi wanita), tetapi harus sesuai dengan norma Isla (warna hitam).

Kode etik peserta ujian tersebut menunjukkan adanya kewajiban bagi para mahasiswi memakai baju kemeja longgar yang berpasangan dengan rok panjang. Jika ditemukan ada mahasiswi yang melanggar kode etik tersebut, misalnya memakai baju kaos, atau baju yang ketat, atau memakai celana panjang, maka yang bersangkutan tidak diperkenankan mengikuti ujian yang berlangsung pada hari itu.

Tampaknya kode etik ini sangat ampuh, karena pada saat Ujian Akhir Semester berlangsung, semua mahasiswi mematuhinya dengan baik. Begitu patuhnya terhadap kode etik tersebut sehingga terkadang ditemukan ada mahasiswi yang membawa dua macam pakaian ketika mengikuti ujian, yakni selain memakai rok, juga membawa celana panjang sebagai cadangan. Rok yang dipakainya itu hanya sebatas berada dalam ruangan ujian. Ketika ujian sudah selesai dan keluar dari ruangan, mereka langsung melepas roknya dan menggantinya dengan celana panjang.

Sebenarnya, kode etik yang dikeluarkan oleh Panitia UAS tersebut bisa diangkat dan dijabarkan lebih luas dalam bentuk peraturan mengenai jilbab di IAI Muhammadiyah Sinjai. Para mahasiswi sendiri menghendaki adanya aturan seperti itu, sebagaimana pengakuan mereka dari hasil angket melalui tabel berikut.

Tabel 2: Distribusi Tanggapan Mahasiswi tentang Perlunya Aturan Resmi Mengenai Model Jilbab

\begin{tabular}{|c|l|c|}
\hline No & \multicolumn{1}{|c|}{ Perlu atau Tidaknya Ada Aturan Resmi } & Prosentase \\
\hline 1 & Perlu & 72 \\
2 & Tidak perlu & 28 \\
\hline & Jumlah & 100 \\
\hline
\end{tabular}

Tabel di atas menunjukkan bahwa $72 \%$ dari mahasiswi IAIM Sinjai yang menganggap perlu adanya aturan resmi yang dikeluarkan oleh pimpinan IAIM Sinjai untuk menyeragamkan model jilbab yang dipakai oleh para mahasiswi, supaya jilbab yang mereka pakai benar-benar mencerminkan 
busana Muslimah. Sementara itu, hanya $28 \%$ sisanya yang menganggap tidak perlu ada aturan resmi, sebab model jilbab yang mereka pakai sudah mencerminkan busana Muslimah.

Dari kondisi obyektif yang terjadi pada saat berlangsungnya UAS yang diperkuat oleh pengakuan mayoritas para mahasiswi sendiri melalui hasil angket, dapat disimpulkan bahwa pada dasarnya para mahasiswi tersebut bersedia mematuhi segala aturan yang terkait dengan model jilbab yang harus mereka pakai, jika ada aturan yang dikeluarkan oleh pimpinan IAIM Sinjai.

Oleh karena itu, melalui penelitian ini, penulis menyarankan kepada pimpinan IAIM Sinjai untuk mengeluarkan sebuah aturan yang terkait dengan keseragaman model jilbab untuk para mahasiswi. Model yang disarankan adalah: baju longgar dan rok panjang yang dilengkapi dengan kerudung lebar. Dengan model seperti ini, bentuk/lekuk tubuh mereka akan tersembunyi, sehingga jilbab yang mereka pakai benar-benar sesuai dengan fungsinya sebagai penutup aurat.

\section{Kondisi Obyektif Pemakaian Jilbab}

Dalam penelitian ini, kondisi obyektif mahasiswi IAIM Sinjai dalam memakai jilbab, dapat dipilah atas dua bagian, yaitu: kondisi di dalam kampus dan kondisi di luar kampus.

a. Kondisi Obyektif di dalam Kampus

Sesuai dengan pengamatan penulis, para mahasiswi dalam melakukan aktivitas kampus seharihari sangat bervariasi dalam memakai jilbab. Variasi yang dimaksud adalah sebagai berikut:

1) Sebagian kecil di antara mahasiswi memakai baju longgar dan rok panjang yang dilengkapi dengan kerudung.

2) Sebagian pula di antara mereka memakai baju sempit dan celana panjang biasa yang dilengkapi dengan kerudung.

3) Sebagian pula di antara mereka yang memakai baju kaos yang ketat dan celana panjang levis/jeans yang dilengkapi dengan kerudung.

Jika hasil pengamatan di atas diuji dalam bentuk angket, maka ditemukan adanya kesesuaian dengan pengakuan dari para mahasiswi itu sendiri. Untuk lebih jelasnya kesesuaian tersebut, dapat dikemukakan dalam tabel berikut.

Tabel 3: Distribusi Model Jilbab yang Dipakai Mahasiswi

\begin{tabular}{|c|l|c|}
\hline No & \multicolumn{1}{|c|}{ Model Jilbab yang Dipakai } & Prosentase \\
\hline 1 & Baju longgar, rok panjang, dan kerudung besar & 15 \\
2 & Baju longgar, celana panjang, dan kerudung besar & 1 \\
3 & Baju biasa, rok panjang, dan kerudung biasa & 60 \\
4 & Baju biasa, celana panjang, dan kerudung biasa & 24 \\
\hline & Jumlah & 100 \\
\hline
\end{tabular}

Tabel di atas menunjukkan bahwa dalam melakukan aktivitas sehari-hari di kampus, $15 \%$ dari mahasiswi memakai baju longgar dan rok panjang yang dilengkapi dengan kerudung besar, sementara itu $1 \%$ di antaranya yang memilih celana panjang untuk menyerasikan baju longgar dan kerudung 
besarnya. Selain itu, ada $60 \%$ dari mereka yang memilih baju biasa (baju tidak longgar, bahkan terkadang baju kaos yang ketat) dan rok panjang yang dilengkapi dengan kerudung biasa (bukan kerudung besar), sementara itu $24 \%$ yang memilih memakai celana panjang untuk menyerasikan baju biasa dan kerudung biasanya.

Masing-masing dari mereka itu menganggap bahwa pakaian yang dipakainya adalah jilbab. Artinya, bentuk apapun pakaian yang mereka pakai kalau sudah dilengkapi dengan kerudung, maka secara otomatis pakaian tersebut sudah termasuk jilbab. Dengan demikian, yang mereka pahami sebagai jilbab hanyalah kerudung.

Berbicara tentang model jilbab, para ulama tidak memberi penekanan terhadap model yang dipakai oleh orang-orang Arab (jubah besar dan lonngar). Menurut Ibnu 'Asyur, model jilbab dapat berbeda sesuai dengan keadaan wanita dan adat istiadat mereka (Muhammad Tahir ibn 'Asyur, t.th.: 102). Demikian halnya dengan Nashruddin Baidan, ia mengatakan bahwa pada tempat lain atau di masyarakat tertentu, model pakaian wanitanya tidak mesti serupa dengan model jilbab orang Arab. Boleh saja mereka memakai model pakaian yang mereka sukai, selama pakaian tersebut longgar dan tidak tipis, sehingga bentuk tubuh dan warna kulit tidak kelihatan dari luar (Nashruddin Baidhan, 1999: 123-124).

Mengacu pada pendapat di atas, penggunaan celana panjang (bukan levis/jeans) masih dapat ditoleransi. Namun, penggunaan baju sempit, apalagi baju kaos yang ketat, jelas-jelas tidak dapat ditoleransi, sebab bentuk/lekuk tubuh wanita tetap akan tampak dengan jelas. Demikian halnya dengan kerudung diharuskan yang lebar, supaya dapat menutup dada pemakainya.

\section{E. Kondisi Obyektif di Luar Kampus}

Seperti halnya sewaktu berada di kampus, jilbab yang mereka pakai ketika berada di luar kampus tidak mengalami perubahan model, sebab busana yang mereka pakai di kampus, itu pula yang dipakai di luar kampus. Kenyataan lain yang penulis temukan di beberapa tempat kost mahasiswi yang ada di sekitar kampus adalah sebagai berikut:

1. Sebagian kecil di antara mahasiswi yang tidak pernah melepas jilbabnya, meski mereka sedang berada di rumah.

2. Sebagian pula di antara mereka melepas jilbabnya ketika sedang berada di rumah, tetapi jilbabnya dipasang kembali ketika akan keluar rumah, seperti ke pasar, ke toko, ke rumah teman, atau ke tempat rekreasi.

3. Sebagian kecil dari mereka yang apabila sudah meninggalkan kampus, maka jilbabnya pun sudah terlepas, baik ketika sedang berada di rumah maupun ketika keluar rumah.

Jika hasil pengamatan penulis di atas dikaitkan dengan pengakuan dari para mahasiswi itu sendiri melalui angket, maka ditemukan adanya kesesuaian, sebagaimana dapat dilihat pada tabel berikut. 
Tabel 4: Distribusi Waktu dan Tempat para Mahasiswi Memakai Jilbab

\begin{tabular}{|c|l|c|}
\hline No & \multicolumn{1}{|c|}{ Waktu dan Tempat Memakai Jilbab } & Prosentase \\
\hline 1 & Meski tinggal di rumah & 8 \\
2 & Di kampus dan acara keislaman & 18 \\
3 & Setiap keluar rumah & 61 \\
4 & Khusus mengikuti kegiatan kampus & 13 \\
\hline & Jumlah & 100 \\
\hline
\end{tabular}

Dari tabel di atas diketahui bahwa $8 \%$ mahasiswi yang sangat konsisten memakai jilbab, meski mereka tinggal di rumah. $18 \%$ di antara mereka memakai jilbabnya bila mengikuti acara yang bernuansa Islam di luar kampus, seperti mengikuti acara peringatan Maulid Nabi Muhammad saw., atau peringatan Isra' dan Mi'raj, atau acara Halal bi Halal. 61 \% dari mereka yang memakai jilbabnya jika ingin keluar rumah, baik ke kampus, ke pasar, ke rumah teman, maupun ke tempat rekreasi. Sementara itu, $13 \%$ sisanya yang hanya memakai jilbab apabila sedang mengikuti kegiatan kampus.

Bagi mereka yang memakai jilbab meski tinggal di rumah atau mereka yang memakai jilbab jika ingin beraktivitas di luar rumah, tidak akan disoroti dalam penelitian ini, sebab memang demikianlah tujuan jilbab, yaitu agar aurat wanita tidak kelihatan oleh orang lain. Yang menjadi sorotan dalam penelitian ini adalah mereka yang hanya memakai jilbabnya jika mengikuti kegiatan kampus dan ditambah dengan kegiatan keagamaan di luar kampus, atau sama sekali melepas jilbabnya jika sudah beraktivitas di luar kampus. Dalam kaitan ini, Maulana Muhammad Ali membolehkan wanita Muslimah melepas kerudungnya jika ia keluar rumah untuk memenuhi kebutuhan duniawinya (Maulana Muhammad Ali, 1977: 441). Qasim Amin juga berpendapat demikian. Ia mengatakan bahwa jika pemakaian hijab itu dipahami secara sempit dan kaku, tentunya akan membatasi gerak-gerik wanita dalam berkarya. Sebagai contoh adalah: Tidak mungkin seorang wanita yang memakai hijab dapat bekerja dengan sukses di bidang industri, perdagangan, atau pertanian. Menurutnya, wanita muslimah boleh menampakkan sebagian anggota tubuhnya di depan orang lain, sesuai dengan adat istiadat yang berlaku. Karenanya, jika pemakaian hijab itu dipahami secara sempit dan kaku, maka tentunya gerak-gerik wanita menjadi terbatas dalam kehidupan bermasyarakat. Bagaimana mungkin seorang wanita miskin yang memakai hijab dapat berusaha mencari nafkah di bidang industri? Bagaimana mungin seorang pembantu yang memakai hijab dapat melayani kebutuhan rumah tangga tuan laki-lakinya? (Qasim Amin, t.th.: 81-84).

Dengan mempertimbangkan pendapat di atas, maka mahasiswi yang melepas jilbabnya karena melakukan aktivitas yang tidak cocok dengan pakaian jilbab, maka perbuatannya itu dapat ditoleransi karena dapat dikatagorikan sebagai darurat. Namun, jika aktivitasnya itu tidak terganggu dengan jilbab, maka tidak ada alasan bagi mereka untuk melepas jilbabnya. Prilaku memakai jilbab tersebut tidak hanya dituntut selama terdaftar sebagai mahasiswi IAIM, tetapi mereka tetap harus 
mempertahankannya setelah lulus dari IAIM. Tabel berikut ini akan mengetengahkan janji mereka untuk tetap memakai jilbab setelah lulus dari IAIM.

Tabel 5: Distribusi Pengakuan Mahasiswi untuk Berjilbab Setelah Lulus dari IAIM Sinjai

\begin{tabular}{|c|l|c|}
\hline No & \multicolumn{1}{|c|}{ Setelah Lulus dari IAIM Sinjai } & Prosentase \\
\hline 1 & Tetap memakai jilbab jika mengikuti kegiatan keagamaan & 18 \\
2 & Tetap memakai jilbab jika keluar rumah & 74 \\
3 & Tetap memakai jilbab meski tinggal di rumah & 8 \\
\hline & Jumlah & 100 \\
\hline
\end{tabular}

Tabel di atas menunjukkan bahwa $18 \%$ dari para mahasiswi yang berjanji, meski mereka telah menyelesaikan studinya di IAIM Sinjai, tetap akan memakai jilbab bila mengikuti kegiatan yang bernuansa ke-Islaman. Sementara itu, 74 \% lainnya yang berjanji akan tetap memakai jilbab apabila mereka melakukan aktivitas di luar rumah. Sedangkan $8 \%$ sisanya berjanji akan tetap mengenakan jilbab, meski mereka tinggal di rumah.

Kalau tabel 5 di atas dikaitkan dengan tabel 4 sebelumnya, tampak adanya pengakuan dari para mahasiswi untuk berubah sikap. Dari $13 \%$ yang semula mengaku tidak memakai jilbab kecuali ketika masuk kampus, ternyata mereka berjanji akan tetap memakai jilbab setelah keluar dari IAIM Sinjai. Mungkin janji mereka itu hanya sekadar janji belaka yang tidak akan mereka penuhi, atau mereka benar-benar akan mengubah pola pikir dan sikapnya tentang kewajiban memakai jilbab.

1. Persepsi Mahasiswa tentang Memakai Jilbab

Sebelum ditanyakan tentang persepsi mereka mengenai kewajiban berjilbab, terlebih dahulu penulis menanyakan tentang sejak kapan mahasiswi tersebut memakai jilbab, apakah sebelum atau setelah terdaftar sebagai mahasiswi IAIM. Jawaban mereka akan dikemukakan dalam bentuk tabel sebagai berikut:

Tabel 6: Distribusi Awal Memakai Jilbab Berdasarkan Jenjang Pendidikan

\begin{tabular}{|c|l|c|}
\hline No & \multicolumn{1}{|c|}{ Jenjang Pendidikan } & Prosentase \\
\hline 1 & SD/MI & 6 \\
2 & SLTP/MTs & 23 \\
3 & SLTA/MA & 22 \\
4 & IAIM & 49 \\
\hline & Jumlah & 100 \\
\hline
\end{tabular}

Dari tabel di atas diketahui bahwa $6 \%$ dari mahasiswi IAIM telah mengenakan jilbab sejak mereka menempuh jenjang pendidikan SD/MI. Diperkirakan bahwa $6 \%$ tersebut telah memakai jilbab karena mereka menempuh jenjang pendidikan di MI. Sementara itu, $23 \%$ di antara mereka 
yang sudah memakai jilbab sejak berada pada tingkat SLTP/MTs dan $22 \%$ setelah berada di tingkat SLTA/MA. Mereka yang memakai jilbab di SLTP dan SLTA itu, pada umumnya atas kemauan mereka sendiri. Berbeda dengan di MTs dan MA, mereka memakai jilbab karena merupakan peraturan sekolah. Adapun yang mengenal jilbab setelah berada di IAIM, jumlahnya cukup banyak, yaitu $49 \%$. Tentu saja mereka yang disebutkan terakhir ini memakai jilbab bukan atas kemauan sendiri tetapi karena harus mengikuti tradisi yang berlaku di Kampus IAIM Sinjai.

Dengan demikian, dapat diketahui bahwa hampir $50 \%$ mahasiswi IAIM yang terdaftar sekarang ini, tidak pernah mengenal jilbab sebelum menjadi mahasiswi. Itu artinya, selama mengikuti jenjang pendidikan dari SD s/d SLTA, mereka memakai pakaian yang memperlihatkan leher ke atas, siku sampai ujung jari tangan, dan lutut ke bawah.

Bentuk pakaian yang disebutkan terakhir merupakan bentuk pakaian yang pada umumnya dipakai oleh wanita Indonesia, bahkan sudah menjadi pakaian seragam resmi bagi karyawati perkantoran dan murid/pelajar/siswi SD/SLTP/SLTA.

Meski bentuk pakaian tersebut dianggap tidak bertentangan dengan nilai-nilai Islam menurut hasil diskusi FPI ke 16 Tanggal 28 April 1988 di Jakarta, yang merumuskan hal-hal sebagai berikut:

a. Jilbab bukan merupakan pakaian wajib dalam Islam. Namun, jilbab merupakan salah satu bentuk pakaian yang memiliki nilai ke-Islaman dan tidak bertentangan dengan nilai-nilai keIndonesiaan, apalagi melanggarnya;

b. Rekayasa untuk memikirkan bentuk pakaian penutup aurat yang sesuai dengan nilai-nilai keIslaman dan ke-Indonesiaan, tetap terbuka sesuai dengan kebutuhan dan perkembangan zaman, atau tahapan pembangunan masyarakat Indonesia modern;

c. Mengingat bahwa: (a) menutup aurat adalah wajib bagi wanita Islam, sebagai disebut dalam QS al-Nūr/24: 30-31, (b) kewajiban itu bukan bersifat esensial tetapi aksidental, (c) batasbatas aurat tidak dijelaskan dalam al-Qur'an dan Hadis secara qat 'î, (d) wanita Islam Indonesia harus ikut serta aktif dalam pembangunan nasional sekarang, (e) dan untuk itu mereka memerlukan pakaian yang mempunyai nilai praktis, pragmatis dan tidak mengikat gerak, maka pakaian maksimal memperlihatkan leher ke atas, lengan dari siku ke ujung jari tangan, dan kaki di bawah lutut, dari tubuh wanita adalah bentuk pakaian yang sesuai dan tidak bertentangan dengan nilai-nilai Islam (Hasil Diskusi FPI, 1988: 1-3).

Namun oleh sebagian besar ulama di Indonesia tetap menganggapnya sebagai bentuk pakaian yang belum mencerminkan busana Muslimah, sebab masih menampakkan sebagian tubuh wanita yang disepakati oleh sebagian besar ulama sebagai aurat.

Melakukan perubahan pakaian secara drastis dari yang semula tidak memakai tutup kepala, baju lengan pendek, dan rok pendek; kemudian langsung memakai jilbab (kerudung, baju lengan panjang, dan rok panjang), secara psikologis dapat menimbulkan pengaruh kejiwaan bagi seorang wanita, karena memakai pakaian yang tidak biasanya mereka pakai. Paling tidak, di awal pemakaian 
jilbab tersebut akan menyiksa batin mereka karena belum terbiasa memakainya (M. Quraish Shihab, 2003: 179).

Kalau pengaruh psikologis perubahan pakaian seperti yang disebutkan di atas dikaitkan dengan pengalaman para mahasiswi IAIM, berikut ini akan dikemukakan pengalaman yang mereka alami setelah memakai jilbab melalui tabel berikut.

Tabel 7: Distribusi Pengaruh Psikologis dengan Memakai Jilbab

\begin{tabular}{|c|l|c|}
\hline No & \multicolumn{1}{|c|}{ Perubahan Psikologis } & Prosentase \\
\hline 1 & Biasa-biasa saja karena sudah lumrah dipakai para wanita & 26 \\
2 & Merasa bangga karena bertambah cantik & 1 \\
3 & Merasa bangga karena auratnya tertutup & 73 \\
\hline & Jumlah & 100 \\
\hline
\end{tabular}

Dari tabel di atas ditemukan bahwa $26 \%$ dari mereka, baik yang memakai jilbab ketika masih di SD/MI, SLTP/MTs, SLTA/MA, maupun yang baru memakai jilbab setelah terdaftar di IAIM, tidak mengalami perubahan psikologis karena mereka melihat bahwa jilbab itu sudah lumrah dan banyak dipakai oleh wanita lain. $1 \%$ dari mereka merasa bangga dengan jilbabnya karena semakin menambah kecantikannya. Sementara itu, $73 \%$ merasa bangga memakai jilbab karena auratnya yang selama ini terbuka, sekarang sudah tertutup.

Suatu kesyukuran besar bahwa ternyata dampak psikologis yang dialami oleh para mahasiswi IAIM setelah memakai jilbab bukan dampak negatif, seperti rasa minder atau rasa tidak percaya diri, tetapi yang muncul justeru dampak positif, yaitu merasa bangga dengan pakaian jilbabnya itu karena telah menutup auratnya.

Dengan demikian, dapat dipahami bahwa hampir $75 \%$ dari mereka sebenarnya menyadari bahwa jilbab itu merupakan pakaian penutup aurat, hanya saja kebanyakan dari mereka itu belum terpanggil hati nuraninya menggunakan pakaian penutup aurat tersebut sejak dini, sehingga mereka baru mengenal jilbab setelah terdaftar di IAIM Sinjai.

Kesadaran mereka itu diketahui dari pengakuannya tentang esensi kewajiban berjilbab, yakni apakah sekadar kewajiban kampus atau kewajiban yang ditetapkan oleh agama. Berikut ini akan dikemukakan jawaban mereka melalui tabel berikutnya.

Tabel 8: Distribusi Pola Pikir Mahasiswi tentang Esensi Jilbab

\begin{tabular}{|c|l|c|}
\hline No & \multicolumn{1}{|c|}{ Esensi Kewajiban Berjilbab } & Prosentase \\
\hline 1 & Kewajiban mengikuti aturan kampus & 10 \\
2 & Kewajiban yang ditetapkan agama & 90 \\
\hline & Jumlah & 100 \\
\hline
\end{tabular}

Tabel di atas menunjukkan bahwa $10 \%$ dari mahasiswi IAIM yang memahami bahwa memakai jilbab itu sekadar sebagai peraturan yang ditetapkan oleh Kampus IAIM, sedangkan $90 \%$ dari mereka memahaminya sebagai kewajiban yang ditetapkan oleh agama. 
Dengan menganggap sebagai kewajiban berdasarkan peraturan agama, maka konsekuensinya adalah harus dilaksanakan. Artinya, jika tidak memakai jilbab, maka mereka melanggar ketentuan agama. Tabel berikut ini akan menunjukkan pendapat mereka tentang akibat hukum orang yang tidak memakai jilbab.

Tabel 9: Distribusi Pola Pikir Mahasiswi tentang Akibat Hukum Bagi yang Tidak Memakai Jilbab

\begin{tabular}{|c|l|c|}
\hline No & \multicolumn{1}{|c|}{ Akibat Hukum Bagi yang tidak Memakai Jilbab } & Prosentase \\
\hline 1 & Berdosa karena melanggar aturan agama & 78 \\
2 & Tidak berdosa karena hanya melangar aturan kampus & 22 \\
\hline & Jumlah & 100 \\
\hline
\end{tabular}

Tabel di atas menunjukkan bahwa $78 \%$ mahasiswi IAIM berpendapat bahwa wanita yang tidak memakai jilbab berdosa, sebab melanggar ketentuan yang ditetapkan oleh agama. Sementara itu, $22 \%$ di antaranya menganggap bahwa wanita yang tidak memakai jilbab tidak berdosa, sebab hanya melanggar peraturan kampus.

Di sini tampak ketidakkonsistenan sebagian mahasiswi dalam memberikan jawaban, sebab dari $90 \%$ yang semula mengakui bahwa jilbab merupakan pakaian yang diwajibkan oleh agama, ternyata hanya $78 \%$ yang menganggap bahwa wanita yang tidak memakainya akan berdosa. Dengan kata lain, $12 \%$ yang mengakui jilbab sebagai kewajiban agama, tetapi tidak menganggap berdosa wanita yang tidak memakainya.

Bagi mereka yang memahami kewajiban berjilbab sebagai peraturan kampus sehingga tidak menimbulkan dosa bagi yang tidak memakainya, merupakan pendapat yang masih perlu dikaji lebih jauh.

Nashruddin Baidan termasuk pakar yang menganggap bahwa kewajiban berjilbab dalam QS alAhzab/33: 59 bersifat kondisional, bukan bersifat mutlak. Menurutnya, ayat itu turun berkenaan dengan prilaku orang-orang munafik yang mengganggu wanita Muslimah ketika keluar rumah pada malam hari untuk keperluan tertentu. Apabila di suatu tempat atau suatu masa terjadi peristiwa yang serupa, maka di tempat itu para wanita Muslimah wajib memakai jilbab, supaya tidak mendapat gangguan (Nashruddin Baidan, 1999: 120-121).

Pendapat ini sejalan dengan hasil diskusi FPI ke 16 tanggal 28 April 1988 di Jakarta yang salah satu rumusan kesimpulannya mengatakan bahwa jilbab bukan merupakan pakaian wajib dalam Islam. Namun, jilbab merupakan salah satu bentuk pakaian yang memiliki nilai ke-Islaman dan tidak bertentangan dengan nilai-nilai ke-Indonesiaan, apalagi melanggarnya (Hasil Diskusi FPI, 1988: 1-3).

Dengan mempertimbangkan pendapat yang dikemukakan di atas, maka persepsi sebagian kecil mahasiswi IAIM yang menganggap jilbab itu hanya sebagai kewajiban kampus, tidak boleh dipersalahkan total, sebab memiliki dasar pijakan, meski pendapat itu tidak mayoritas.

Adapun pemahaman sebagian besar mahasiswi IAIM yang menganggap jilbab itu sebagai kewajiban agama sehingga wanita Muslimah yang tidak memakainya berdosa, merupakan 
pemahaman yang sesuai dengan pendapat mayoritas ulama. Pendapat inilah yang melandasi semua sekolah agama, termasuk IAIM, sehingga mewajibkan peserta didik z wanitanya memakai jilbab.

\section{PENUTUP}

\section{Kesimpulan}

Konsep ajaran Islam tentang kewajiban menutup aurat dengan berdasar pada QS al-Nür/24: 30 dan 31, maka para ulama sepakat mengenai kewajiban menutup aurat bagi seorang muslim. Hal itu secara eksplisit dapat dipahami dari perintah menahan pandangan dan memelihara kemaluan. Adapun secara implisit, QS al-Nür/24: 31 melarang wanita memperlihatkan perhiasannya, kecuali kepada suaminya dan orang-orang yang terkait hubungan ke-mahram-an dengannya, serta terhadap laki-laki dan anak-anak yang belum mengerti tentang aurat wanita. Namun demikian, para ulama tidak sepakat mengenai batas aurat dari tubuh manusia yang harus selalu ditutup.

Aplikasi peraturan IAIM Sinjai tentang memakai jilbab dalam mengikuti perkuliahan dengan berdasarkan pada Keputusan Menteri Agama Republik Indonesia Nomor 10 Tahun 2003 tentang Statuta IAIM Sinjai, khususnya pada pasal 14 tentang Busana Akademik dan pasal 98 tentang Hak dan Kewajiban Mahasiswa, ternyata belum dapat berjalan secara optimal. Namun satu-satunya aturan IAIM Sinjai yang selama ini dipandang ampuh dalam menyatukan model busana para mahasiswi adalah kode etik yang dikeluarkan oleh Panitia Ujian Akhir Semester (UAS). Ketika akan dilaksanakan UAS, baik pada semester ganjil maupun pada semester genap, sudah dibakukan secara ketat model pakaian yang harus dipakai oleh para peserta ujian melalui Kode Etik.

Mahasiswi IAIM Sinjai memiliki persepsi dan prilaku yang berbeda dalam hal:

a. Kewajiban memakai jilbab. Sebagian besar mahasiswi menganggap jilbab sebagai kewajiban yang telah ditetapkan oleh agama, sehingga jika tidak memakainya menimbulkan dosa. Namun, sebagian kecil menganggapnya sebagai kewajiban kampus belaka, sehingga jika tidak memakainya tidak menimbulkan dosa.

b. Model jilbab. Sebagian besar menganggap variasi model jilbab yang dipakai pada umumnya mahasiswi belum mencerminkan busana Muslimah, sehingga perlu adanya aturan khusus menyangkut keseragaman model jilbab. Namun, sebagian pula menganggap model yang bervariasi itu sudah sesuai dengan esensi busana Muslimah, sehingga tidak diperlukan aturan khusus mengenai keseragaman jilbab.

c. Perilaku memakai jilbab. Sebagian mahasiswi memakai jilbab hanya ketika mengikuti aktivitas kampus, sebagian pula tetap memakai jilbab setiap kali keluar dari rumahnya, malah ada sebagian kecil dari mereka yang tidak pernah melepas jilbab meski tinggal di rumah.

\section{DAFTAR PUSTAKA}

Abi Syuqqah, ‘Abd al-Halim. Tahrīir al-Mar'ah fi 'Așr al-Risālah. Jakarta: Gema Insani Press, 1991. 
Ali, Maulana Muhammad. The Religion of Islam. Jakarta: Dār al-Kutūb al-Islāmiyyah bekerja sama dengan PT Ichtiar Baru-van Hoeve, 1977.

Baidan, Nashruddin. Tafsir bi al-Ra'yi: Upaya Penggalian Konsep Wanita dalam al-Qur'an. Yogyakarta, Pustaka Pelajar, 1990.

Bungin, Burhan. Analisis Data Penelitian Kualitatif: Pemahaman Filosofis dan Metodologis ke Arah Penguasaan Model Aplikasi. Jakarta: PT RajaGrafindo Persada, 2003.

Departemen Agama RI. Al-Qur'an dan Terjemahnya. Jakarta: Proyek Pengadaan Kitab Suci alQur'an, 1986.

. Keputusan Menteri Agama Republik Indonesia Nomor 10 Tahun 2003 tentang Statuta Sekolah Tinggi Agama Islam Negeri Watampone. Jakarta: Departemen Agama RI., 2003.

FPI. Aurat dan Jilbab. Dipresentasikan pada diskusi FPI, Jakarta, 28 April, 1988.

Al-Hanif, Abu Rifqi. Lubis Salam. Analisa Ciri-ciri Wanita Shalihah. Surabaya, Terbit Terang, 1994.

Ibnu Majah, Muhammad Fuad Abd. Baqi Sunan al Hafizh Abi Abdillah Muahammad bin Yaud alQazwiny. Kairo, Darul Haya Kutub Arabiyah, 1948.

Al-Jazariy, 'Abd al-Rahman. Kitab al-Fiqh 'ala Mażăhib al-Arba'ah. Kairo, al-Maktabah alTijariyyah al-Kubra, t.th.

Latif, Syarifuddin. Pembantu Ketua Bidang Kemahasiswaan IAIM Sinjai. Wawancara. Tanggal 20 Februari 2007 di Watampone.

Moleong, Lexy J. Metodologi Penelitian Kualitatif. Bandung, PT Remaja Rosdakarya, 1999.

Munawwir, Ahmad Warson. Al-Munawwir: Kamus Arab-Indonesia. Yogyakarta, Pondok Pesantren al-Munawwir, t.th.

Poerwadarminta, W. J. S. Kamus Umum Bahasa Indonesia. Jakarta, PN Balai Pustaka, 1985.

Al-Qurtubiy, Abiy 'Abdillah Muhammad ibn Ahmad al-Anbariy. Al-Jāmi' li Aḥkām al-Qur'ān. Bairut, Dār al-Fikr al-Nasyr wa al-Tauzi', 1994.

Salim, Nadiyah. Wanita Islam: Kepribadian dan Perjuangannya. Bandung, PT Remaja Rosdakarya, 1994.

Sekolah Tinggi Agama Islam Negeri (IAIM) Watampone. Buku Alumni dan Civitas Akademik Lulusan Sarjana Strata Satu (S1) Jurusan Syariah, Tarbiyah, dan Program Diploma Tahun Akademik 2003-2004.

Shadily, Hassan. et al. Ensiklopedi Indonesia. Jakarta, PT Ichtiar Baru-van Hoeve. 1982.

Shihab, M. Quraish. Wawasan al-Qur'an: Tafsir Maudhu'i atas Pelbagai Persoalan Umat. Bandung, Mizan, 2003.

Sudjana. Metode Statistika. Bandung, Angkasa, 1984.

Suparmoko. M. Metode Penelitian Praktis (Untuk Ilmu-ilmu Sosial dan Ekonomi). Yogyakarta, BPFE, 1991.

Al-Waḥidì, Abī al-Ḥasan ‘Ali. Asbāb al-Nuzūl al-Qur’ān. Miṣr: Dār al-Qiblah, 1984. 